\title{
Improvements of volcanic ash fall forecasts issued by the Japan Meteorological Agency
}

\author{
Yoshihiko Hasegawa ${ }^{1 *}$, Akira Sugai ${ }^{1}$, Yosuke Hayashi ${ }^{1}$, Yuta Hayashi ${ }^{1}$, Shoji Saito ${ }^{1}$ and Toshiki Shimbori ${ }^{2}$
}

\begin{abstract}
Since March 2008, the Japan Meteorological Agency (JMA) has operated a Volcanic Ash Fall Forecast (VAFF) system to issue forecasts of areas in Japan where ash falls are expected following volcanic eruptions. The hazardous effects of ash falls vary according to the quantity of ash generated and have different consequences for agriculture, communication and transport networks, and buildings. The prediction techniques based on the JMA Regional Atmospheric Transport Model were recently revised by the Meteorological Research Institute of JMA to allow predictions of the quantity and areas of ash fall, and areas to be affected by lapilli fall. JMA plans further improvements to the VAFF system to address the needs of people living near active volcanoes and to take into account expert advice in fields such as volcanology, disaster prevention, and broadcasting and medical services. The improved VAFF system will provide three types of information: a regular information before possible eruption, a brief preliminary forecast issued 5-10 minutes after an eruption, and a full forecast issued 20-30 minutes after an eruption. JMA has developed a table to accompany VAFFs that categorizes the hazardous effects for people according to various quantities of ash fall, and provides advice on preparedness measures and actions to be taken when an ash fall occurs. The new VAFF system will also provide predictions of areas of expected lapilli fall. JMA will start operation of the new VAFF system in spring 2015.
\end{abstract}

\section{Introduction}

Since March 2008, the Japan Meteorological Agency (JMA) has operated the Volcanic Ash Fall Forecast (VAFF) system to provide forecasts when ash falls are expected to affect large areas. However, the present system predicts only the areas where ash may fall. A survey of VAFF users conducted in 2012 by JMA in areas close to active volcanoes (e.g. Asamayama, Kirishimayama, and Sakurajima) demonstrated strong demand for forecasts of the quantity of ash falls, prediction of areas of expected lapilli falls, and early issue of VAFFs. Recent studies by the Meteorological Research Institute (MRI) of JMA and an upgrade of the JMA supercomputer system will allow JMA to improve the current system by adding predictions of the quantity of ash falls and information about expected lapilli falls.

Volcanic ash falls affect buildings and many areas of human activity, such as traffic, infrastructure lifelines, agriculture, forestry, fisheries, and human health (e.g.
Mt. Fuji Hazard Map Examination Committee 2004; Horwell and Baxter 2006; Wilson et al. 2012). The hazards differ among these areas, and also according to the quantity of ash falls. Prediction of the quantity of ash falls is important for disaster mitigation or prevention. In March 2013, JMA presented a Proposal for Advanced VAFF at a meeting of the Working Group on Advanced VAFF. Based on that proposal, JMA will update the existing VAFF system to incorporate new capabilities and create a distribution system for forecasts. JMA plans to have the new system operational in spring 2015.

\section{Present VAFF system}

Under the present system, VAFFs are issued by JMA 30 to 40 minutes after large eruptions. The criteria for issuance of VAFFs are provided in Table 1 . The VAFF is a graphical format including forecasts of the areal extent of ash fall at one-hour intervals for six hours after the eruption (Figure 1). VAFFs are sent to authorities at

\footnotetext{
* Correspondence: y-hasegawa@met.kishou.go.jp

'Japan Meteorological Agency, Chiyoda-ku, Tokyo, Japan

Full list of author information is available at the end of the article
}

\section{实}

(c) 2015 Hasegawa et al.; licensee Springer. This is an Open Access article distributed under the terms of the Creative Commons Attribution License (http://creativecommons.org/licenses/by/4.0), which permits unrestricted use, distribution, and reproduction in any medium, provided the original work is properly credited. 
Table 1 JMA Criteria for issue of VAFFs (effective March 2014)

\begin{tabular}{ll}
\hline Volcano & Criteria \\
\hline Asamayama & $\begin{array}{l}\text { Observation of an eruption of plume height } \\
\geq 3000 \mathrm{~m} \text { above the crater rim. For plume } \\
\text { heights of } 1000-3000 \mathrm{~m} \text {, a VAFF may be } \\
\text { issued under some circumstances. }\end{array}$ \\
& $\begin{array}{l}\text { Observation of an eruption of plume height } \\
\geq 2000 \mathrm{~m} \text { above the crater rim. }\end{array}$ \\
Kirishimayama & Observation of an eruption of plume height \\
(Shinmoedake) & 20,2013 ) above the crater rim. \\
Sakurajima & Observation of an eruption plume height of \\
& $\geq 3000 \mathrm{~m}$ above the crater rim.
\end{tabular}

affected prefectures, disaster prevention agencies, and JMA branch offices and posted on the JMA website.

VAFFs have been issued for eruptions at Asamayama, Kirishimayama, and Sakurajima volcanoes from March 2008 to March 2014 (Figure 2 and Table 2).

\section{Contributions to improvement of the VAFF system}

Improvements to ash-fall forecasts

Predictions of the areas and quantities of ash fall, and of areas of lapilli fall, have been improved in accuracy as a result of recent studies by MRI (Hashimoto et al. 2012; Shimbori et al. 2014). These studies document the use of weather radar systems to accurately measure the heights of volcanic plumes, which provide important initial data for predictive use. The recent upgrade of the JMA supercomputer system has also improved the precision of ash-fall and lapilli-fall predictions.

MRI applied the methodology described by Shimbori et al. (2014) to the 2011 eruption from the Shinmoedake crater of Kirishimayama volcano to derive predicted ash-fall data that matched observed data reasonably well (Figure 3; Shimbori et al. 2014). JMA will incorporate this methodology in the new VAFF system.

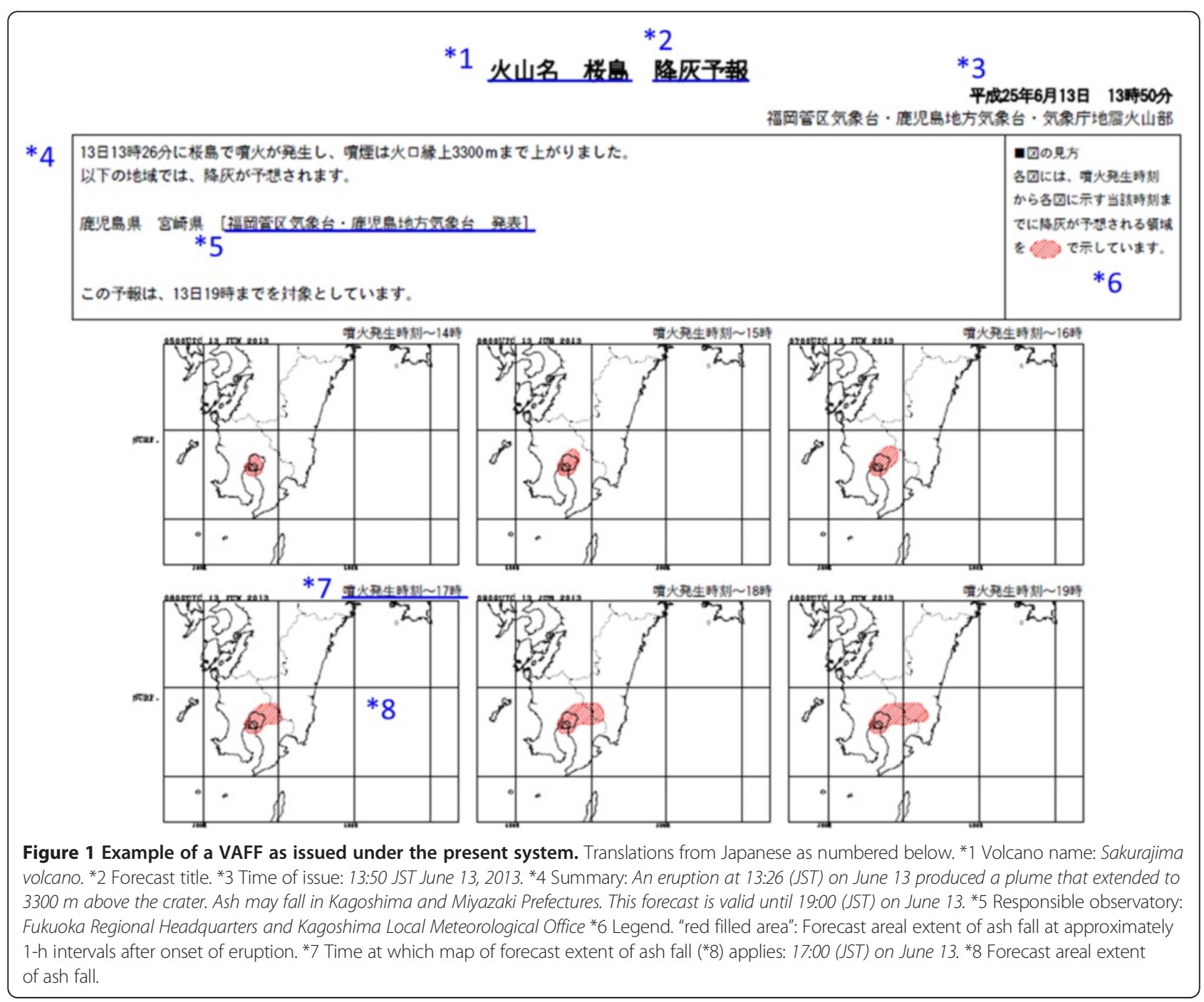




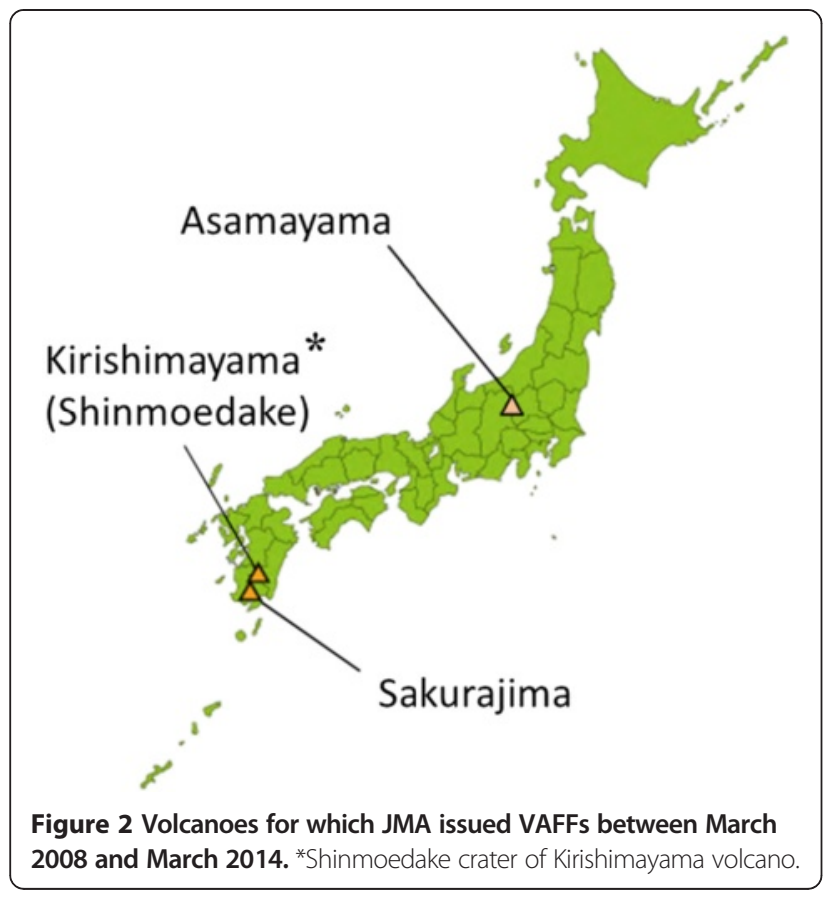

Technical methods of the VAFF are as follows: We first estimate the total mass of tephra from an eruption on the basis of plume height and eruption duration (Sect. A.2 of Shimbori et al. (2010) based on Suzuki (1990)) and then use the JMA Regional Atmospheric Transport Model (JMA-RATM) driven by the grid point values of the numerical weather prediction model to predict the quantity of ash fall (thickness of predicted ash layer), the extent of the area of ash fall and the area in which lapilli are expected to fall (Figure 4).

\section{Survey to determine needs of VAFF users}

During March to September 2012, JMA carried out a survey to determine the needs of VAFF users in areas near volcanoes where there have been recent ash falls. Participants included disaster prevention organizations

Table 2 Number of VAFFs issued by JMA from March 31, 2008 to March 31, 2014

\begin{tabular}{|c|c|c|c|}
\hline & Asamayama & $\begin{array}{l}\text { Kirishimayama } \\
\text { (Shinmoedake) }\end{array}$ & Sakurajima \\
\hline 2008 (Mar 31-Dec) & & & 2 \\
\hline 2009 & $1^{1}$ & & 3 \\
\hline \multicolumn{4}{|l|}{2010} \\
\hline 2011 & & $39^{2}$ & 1 \\
\hline 2012 & & & 4 \\
\hline 2013 & & & $52^{3}$ \\
\hline 2014 (Jan-Mar) & & & 6 \\
\hline
\end{tabular}

${ }^{1}$ Eruption on February 2, 2009.

${ }^{2}$ Eruptions from January 26 to April 18, 2011.

${ }^{3}$ Criterion for issue of VAFF changed on May 20, 2013. near Sakurajima, Kirishimayama, and Asamayama volcanoes (227 responses), local communities near those three volcanoes (386 responses), and local government authorities near 47 other active volcanoes in Japan (116 responses). The 47 volcanoes were selected on the recommendation of the Coordinating Committee for Prediction of Volcanic Eruption, a consultant body that advises the Director General of JMA.

Questions in the survey addressed VAFF users' needs in terms of the specific types of information they require, the timing of issue of VAFFs, and their means of access to VAFFs. Respondents were asked to consider their needs for VAFFs issued at three stages: before an eruption, immediately after the onset of an eruption, and after an eruption.

The result of the survey showed strong demand for early forecasts of the onset time and severity of ash fall and the areas to be affected, and information about areas to be affected by lapilli fall. The full survey results were published by JMA (2013).

\section{Working group on advanced VAFF}

JMA formed a Working Group on Advanced VAFF, which held meetings on July 5 and November 8, 2012, and February 19, 2013. The 16-member group included representatives from disaster prevention organizations, agricultural organizations, medical and broadcasting services, local government bodies, and volcanologists. The working group considered the results of the 2012 survey and sought to identify ways of improving the VAFF system to provide more-effective disaster mitigation. Matters discussed included how and what information should be provided, the conditions under which VAFFs should be issued, and appropriate forecasts for affected communities for various quantities of ash fall.

Outcomes of the meetings were published in March 2013 (Working Group on Advanced VAFF 2013b) and are summarized below.

VAFFs should be issued when the forecast quantity of an ash fall is likely to affect local communities or the utilities they depend on in their daily life.

VAFFs should be easy for people to understand and act upon, and should include information about forecast lapilli falls.

VAFFs should be issued at three stages:

Before a possible eruption: regular information, including forecasts of areas that may be affected by ash fall and the likelihood of lapilli fall.

As soon as possible after the onset of an eruption: preliminary release of a brief forecast of the quantity of ash fall, areas to be affected, and the likelihood of lapilli fall. After an eruption: when sufficient data are available, a detailed forecast of when ash fall will start and its quantity and areas to be affected. 


\section{a}

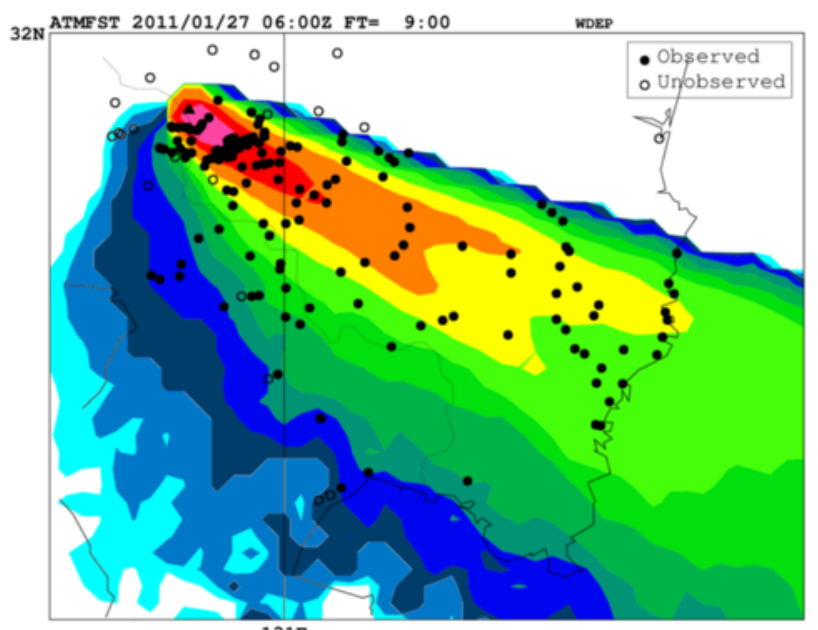

WDEP CNT 10000.00 mox $=\frac{131 \mathrm{E}}{1.01 \mathrm{E}+05} \mathrm{MIN}=0.00 \mathrm{E}+00$

VALID $=01 / 28 \quad 00: 001$

\section{b}

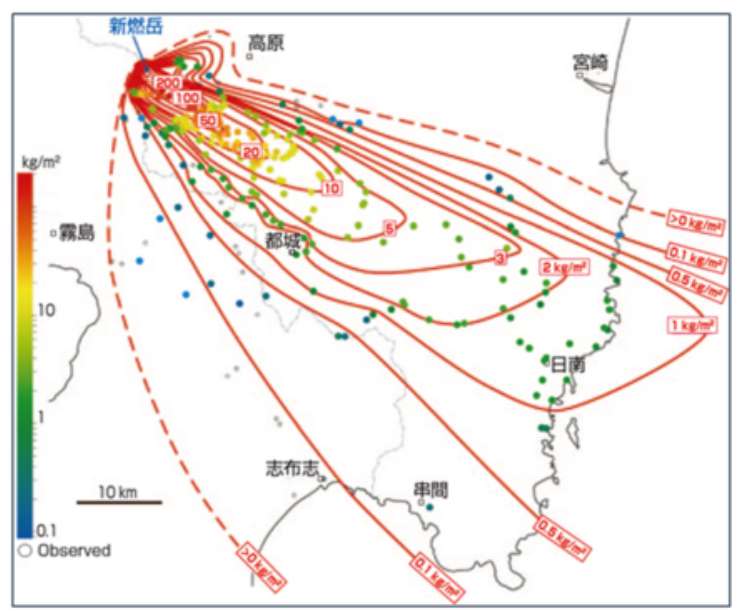

\section{$0.10 .3 \quad 1 \quad 3 \quad 10 \quad 30100300 \quad 1 \mathrm{k} \quad 3 \mathrm{k} \quad 10 \mathrm{k} 30 \mathrm{k} 100 \mathrm{k}$ g/m2}

Figure 3 Comparison of ash-fall quantity forecast using MRI method and observed ash-fall quantity. (a) Quantitative tephra-fall predictions $\left(\mathrm{g} / \mathrm{m}^{2}\right)$ from 15:00 JST on January 26 until 00:00 JST on January 28 based on JMA-RATM for the 2011 eruption at Shinmoedake volcano. Initial values for plume height and eruption duration based on data from the JMA weather radar network (Shimbori et al. 2014). Legend: $\bullet$, ash fall observed; o, no ash fall observed. (b) Ash-fall observations $\left(\mathrm{kg} / \mathrm{m}^{2}\right)$ for eruptions at Shinmoedake volcano during January 26-27, 2011 (Furukawa 2011). Colored dots correspond to the color bar at the left side in the figure (b).

VAFFs should categorize ash falls according to quantity, describe the potential impacts of each category on human health, transport systems, and utilities, and provide advice as to the appropriate actions to be taken by the general public during and after ash falls.

There should be a trial VAFF distribution to local government bodies near Sakurajima volcano incorporating

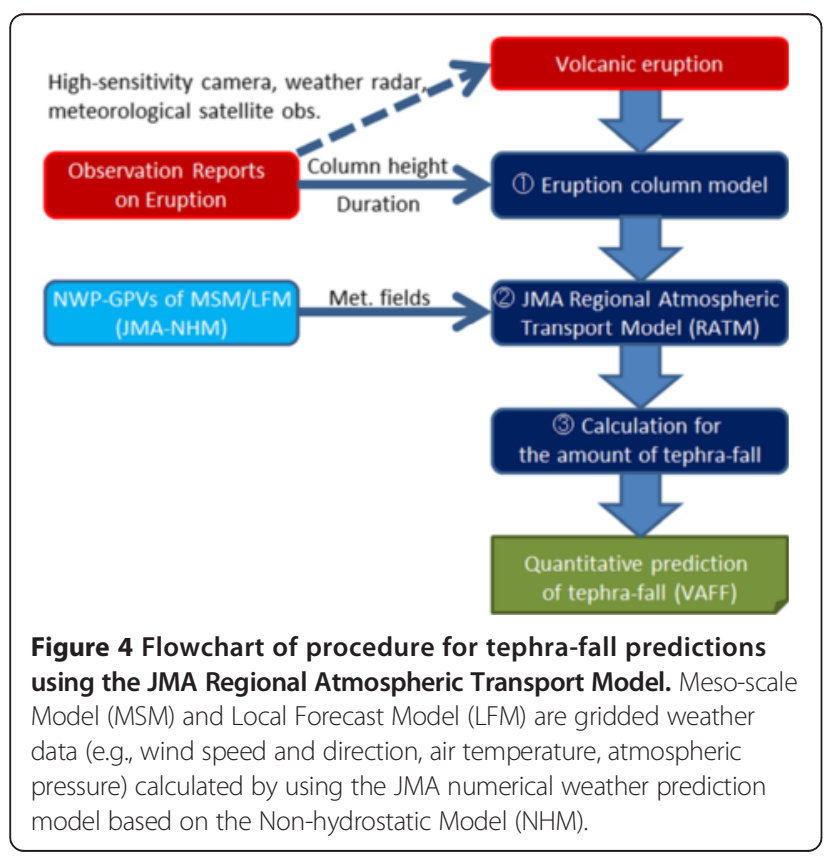

the recommended improvements to the VAFF system and seeking their feedback.

Case studies are needed that illustrate the effects and appropriate actions for the general public for different quantities of ash fall.

Where applicable, results of volcanological studies undertaken at universities and other research institutions should be used to improve the VAFF system.

\section{Future volcanic ash fall forecasts}

JMA is preparing to implement the improved VAFF system based on the Proposal for Advanced VAFF (Working Group on Advanced VAFF 2013b). The major improvements (Table 3) are as follows:

Sequential release of three types of VAFF: regular information issued before an possible eruption, a brief preliminary forecast issued 5-10 minutes after an eruption starts, and a full forecast issued 20-30 minutes after the eruption.

VAFFs will be issued in Japanese in both graphical and text formats.

JMA will provide a table categorizing ash falls by quantity (little, moderate, and much), documenting the likely effects on the general public, and advising them of necessary preparedness measures (Figure 5).

VAFFs will be issued for ash-fall quantities in the moderate and much categories (Figure 5).

VAFFs will provide predictions of areas of lapilli fall (lapilli size $\geq 1 \mathrm{~cm}$ ) separated from predictions of ash fall 
Table 3 Comparison of present and proposed VAFFs

\begin{tabular}{|c|c|c|c|c|}
\hline & Present VAFF & Proposed VAFF & & \\
\hline \multirow{2}{*}{$\begin{array}{l}\text { Type and timing of } \\
\text { forecast }\end{array}$} & Volcanic Ash Fall Forecast & Regular Information & Preliminary Forecast & Full Forecast \\
\hline & $\begin{array}{l}\text { Issued within } 30-40 \text { min of } \\
\text { onset of eruption }\end{array}$ & $\begin{array}{l}\text { Issued regularly (e.g. } 3 \text { hourly) } \\
\text { before possible eruption }\end{array}$ & $\begin{array}{l}\text { Issued within 5-10 min of } \\
\text { onset of eruption }\end{array}$ & $\begin{array}{l}\text { Issued within 20-30 min of } \\
\text { onset of eruption }\end{array}$ \\
\hline Contents & $\begin{array}{l}\text { Forecast }{ }^{1} \text { of situation at six } \\
1-\mathrm{h} \text { intervals after onset of } \\
\text { eruption: Ash fall area. } \\
\text { Prefectures where ash may } \\
\text { fall }\end{array}$ & $\begin{array}{l}\text { Forecast }{ }^{1} \text { for an assumed } \\
\text { eruption: Ash-fall area. } \\
\text { Lapilli-fall area. Recommended } \\
\text { actions for affected } \\
\text { communities }\end{array}$ & $\begin{array}{l}\text { Forecast }{ }^{2} \text { for first hour after } \\
\text { onset of eruption: Ash-fall area } \\
\text { and quantity. Municipalities } \\
\text { affected. Lapilli-fall area. } \\
\text { Recommended actions for } \\
\text { affected communities }\end{array}$ & $\begin{array}{l}\text { Forecast }^{2} \text { of situation at six } \\
\text { 1-h intervals after onset of } \\
\text { eruption: Ash-fall area and } \\
\text { quantity. Municipalities } \\
\text { affected. Start of ash fall } \\
\text { for each municipality. } \\
\text { Recommended action for } \\
\text { affected communities }\end{array}$ \\
\hline
\end{tabular}

${ }^{1}$ Meso-scale Model used for forecasts (see Figure 4).

${ }^{2}$ Local Forecast Model used for forecasts (see Figure 4).

and provide recommended actions for people in areas affected, because ash fall and lapilli fall pose different hazards. Ash fall can, for example, cause a loss of traction on roadways whereas lapilli fall can break windshields of cars. Furthermore, some lapilli fall damage can occur even in areas of moderate ash fall. In addition, the prediction of area of lapilli fall was also strongly needed from users of VAFF (JMA 2013).

\section{Types of forecast}

Because the effects of ash fall manifest quickly after an eruption, VAFFs must be issued as early as possible. However, the information available at the start of an eruption lacks accuracy. Considering the needs of VAFF users and the technical limitations of ash-fall predictions, JMA will issue three types of VAFF, as described below (Figure 6).

\begin{tabular}{|c|c|c|c|c|c|c|}
\hline \multirow{3}{*}{$\begin{array}{c}\text { Category } \\
\text { (categorized } \\
\text { according to } \\
\text { quantity) }\end{array}$} & \multicolumn{3}{|c|}{ Contents } & \multicolumn{2}{|c|}{ Effects, Action and Preparedness } & \multirow{3}{*}{ Other effects } \\
\hline & \multirow{2}{*}{$\begin{array}{c}\text { Ash thickness } \\
\text { 【Keyword } \\
\text { for action】 }\end{array}$} & \multicolumn{2}{|c|}{ Ashfall condition ${ }^{* 1}$} & \multirow{2}{*}{ People } & \multirow{2}{*}{ Driver } & \\
\hline & & Ash on roads & Visibility & & & \\
\hline Much & $\begin{array}{c}\geqq 1 \mathrm{~mm} \\
\text { 【Stay } \\
\text { Indoors】 }\end{array}$ & Covered completely & $\begin{array}{c}\text { Poor } \\
\text { (Heavy ashfall) }\end{array}$ & $\begin{array}{l}\text { Stay Indoors } \\
\text { Ash worsen } \\
\text { symptoms of chronic } \\
\text { asthma or pulmonary } \\
\text { emphysema, and may } \\
\text { cause trouble of eyes, } \\
\text { nose, throot or } \\
\text { respiratory organs of } \\
\text { some healthy people. }\end{array}$ & $\begin{array}{l}\text { Keep off driving } \\
\text { Closure of roads or } \\
\text { limitation of speed for } \\
\text { vehicles are needed due } \\
\text { to poor visibility by } \\
\text { ashfall or blown-up ash. }\end{array}$ & $\begin{array}{l}\text { Insulator coated by } \\
\text { ash has a risk of } \\
\text { power failure. } \\
\text { Water quality may } \\
\text { be deteriorated } \\
\text { and water supply } \\
\text { may be forced to } \\
\text { suspend }\end{array}$ \\
\hline Moderate & $\begin{array}{c}\geqq \begin{array}{c}0.1 \mathrm{~mm} \\
\text { and } \\
<1 \mathrm{~mm}\end{array} \\
\text { 【Attention】 }\end{array}$ & $\begin{array}{c}\text { Road markings } \\
\text { nearly obscured }\end{array}$ & $\begin{array}{c}\text { A little low } \\
\text { (Visible ashfall) }\end{array}$ & $\begin{array}{l}\text { Put on mask } \\
\text { Ash may worsen } \\
\text { symptoms of chronic } \\
\text { asthma or pulmonary } \\
\text { emphysema. }\end{array}$ & $\begin{array}{l}\text { Drive slowly } \\
\text { Visibility may be reduced } \\
\text { when intense ashfall in } \\
\text { short time is observed. } \\
\text { Road markings may be } \\
\text { obscured. }\end{array}$ & $\begin{array}{l}\text { Crops as rice may } \\
\text { be damased. } * 2 \\
\text { Railway service } \\
\text { may be suspended } \\
\text { due to point failure. }\end{array}$ \\
\hline Little & $<0.1 \mathrm{~mm}$ & Thin deposit & $\begin{array}{c}\text { Normal } \\
\text { (Slightly visible ashfall) }\end{array}$ & $\begin{array}{l}\text { Close windows } \\
\text { Ash adhere to } \\
\text { one' s clothing or } \\
\text { body. } \\
\text { Ash in the eyes } \\
\text { makes some pain. }\end{array}$ & $\begin{array}{l}\text { Clean up } \\
\text { windshield } \\
\text { Adherence of ash to } \\
\text { car's windshield may } \\
\text { cause reduction of } \\
\text { visibility. }\end{array}$ & $\begin{array}{l}\text { Flight operation } \\
\text { is suspended }\end{array}$ \\
\hline & & & $\begin{array}{l}\text { ※1 Photo } \\
\text { ※2 The M }\end{array}$ & $\begin{array}{l}\text { JMA. Kagoshima Ci } \\
\text { =uji Hazard Map Exar }\end{array}$ & $\begin{array}{l}\text { and Minami-Nippon Shir } \\
\text { nation Committee (200) }\end{array}$ & un (corp). \\
\hline
\end{tabular}




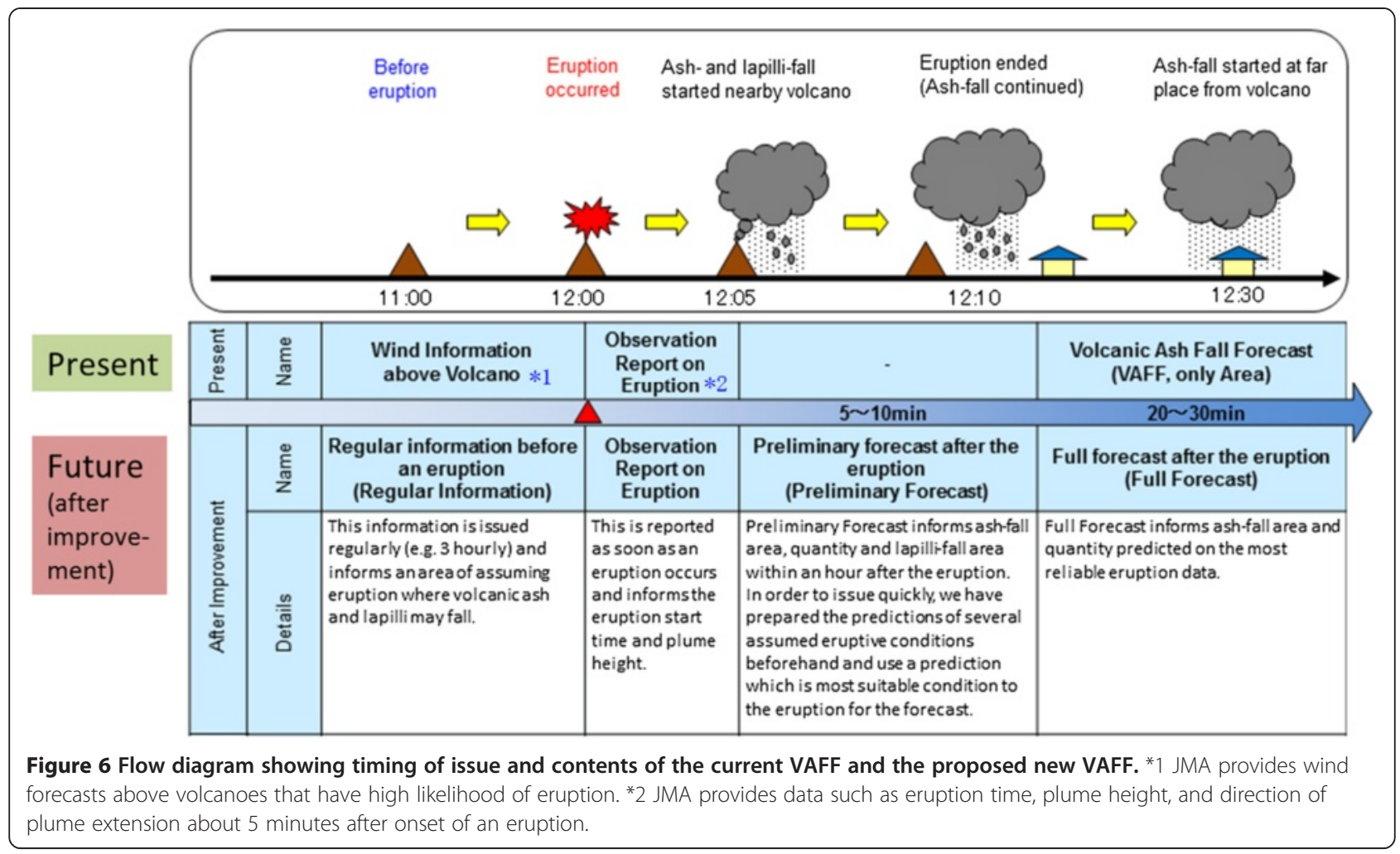

\section{Information issued before an eruption (Regular Information)}

This information will be issued regularly (e.g. 3 hourly) when there is a possibility that an eruption may occur to provide information on potential areas of ash fall and lapilli fall so that local communities can prepare (Figure 7).

Since the 1980s, JMA has issued current and forecast information about winds above Sakurajima volcano at regular intervals (e.g. twice daily) to allow local residents to prepare for possible ash fall.

\section{Brief forecast issued immediately after an eruption (Preliminary Forecast)}

The Preliminary Forecast will be issued within 5-10 minutes of the onset of an eruption. It will be based on JMA's standard 'Observation Report on Eruption' (eruption time, plume height and direction of movement) and will provide initial forecasts of ash-fall and lapilli-fall areas (Figure 8). The Preliminary Forecast will be important for communities close to the volcano.

To facilitate early issue, JMA has prepared in advance various model forecasts for different conditions (eruption time, plume height, wind direction). When an eruption starts, JMA will use the model forecast that best fits the observed conditions for the Preliminary Forecast.

\section{Full Forecast issued after the eruption (Full Forecast)}

The Full Forecast will be issued within 20-30 minutes of the onset of an eruption and will contain accurate forecasts of the area and quantity of ash fall. It will give communities living farther from the volcano time to make appropriate preparations for ash fall (Figure 9). For the Full Forecast, JMA will improve the accuracy of plume height estimates of the previously issued Preliminary Forecast by using weather radar and meteorological satellite data in addition to visual observations.

\section{Format of VAFFs}

VAFF information will be provided in the following formats.

Textual information will be provided in Extensible Markup Language (XML).

Graphical information will be provided in Portable Document Format (PDF) format.

For specialist users, quantitative forecasts $\left(\mathrm{g} / \mathrm{m}^{2}\right)$ of ash fall will be provided as numerical data at the JMA website.

\section{Categories of ash-fall quantity}

Quantitative predictions of the amount of ash fall (expressed in $\mathrm{g} / \mathrm{m}^{2}$ ) include some errors and may be difficult for non-specialist VAFF users to understand. 


\section{${ }^{* 1}$ 炎山名 拉岛 㦀区予转(定時)}

平成26年11月7日059800分

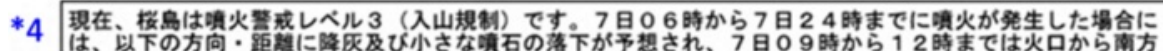

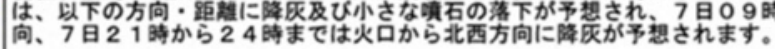

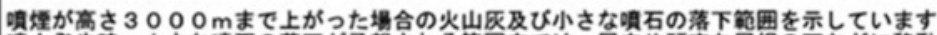

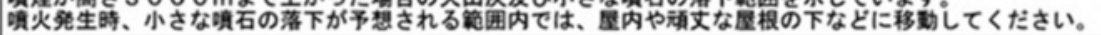
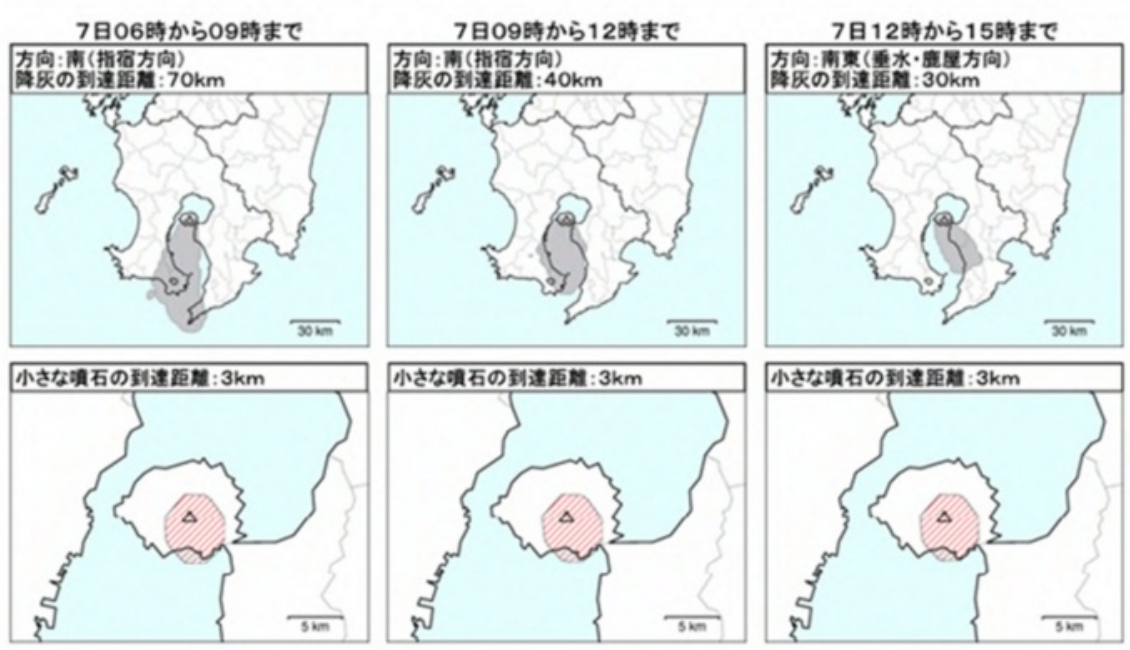

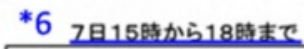

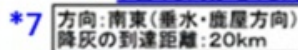

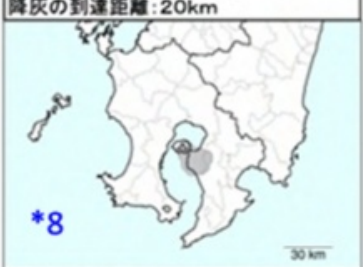

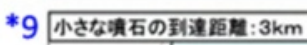

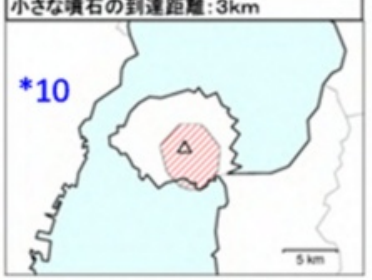

7日18時から219㔀をて

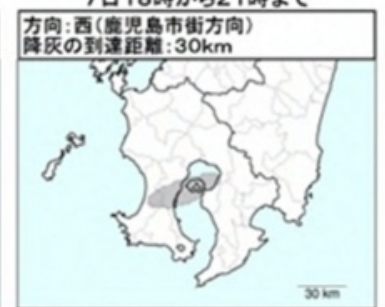

小さな唤石の到连频骨: $1 \mathrm{~km}$

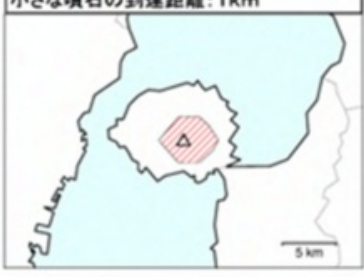

7日21時から24日sまて

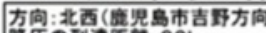

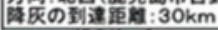
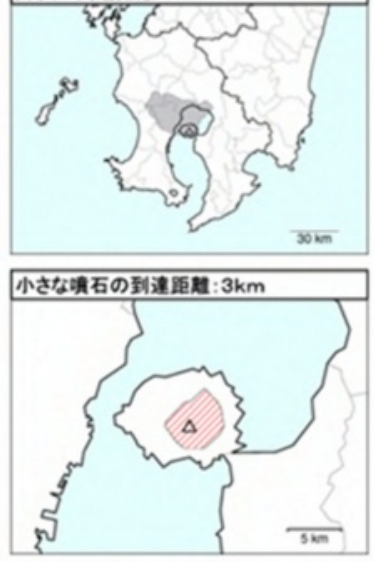

*5

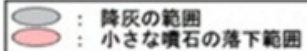

Figure 7 Sample of Regular Information (graphical format) in the new VAFF format. Translations from Japanese as numbered below. *1 Volcano name: Sakurajima volcano. *2 Information title. *3 Time of issue and source: Issued at 05:00 JST on November 7, 2014, by Seismology and Volcanology Department of JMA. *4 Summary: Forecasts of areal extents of ash fall and lapilli fall for possible eruptions at three-hour intervals between 06:00 and 24:00 JST on November 7 are provided by the maps below. The forecast of areal extent of ash fall between 09:00 and 12:00 JST is forecasted to southern direction and that between 21:00 and 2400 JST is forecasted to north-west direction. Forecast areas of ash fall and lapilli fall are based on an eruption producing a $3000 \mathrm{~m}$ vertical plume above the crater. People in areas where lapilli fall is forecast should stay indoors or take refuge under a solid roof. *5 Legend: Forecast areal extents of ash fall and lapilli fall. "Gray filled area": Ash fall. "Red filled area": Lapilli fall ( $\geq 1 \mathrm{~cm}$ size). *6 Annotation of time of eruption: 15:00 - 18:00 JST on November 7. *7 Direction and distance from the crater to maximum extent of ash fall area. Name of localities affected is provided in parentheses: Direction and distance are south-east and $20 \mathrm{~km}$, respectively (direction of Tarumizu city and Kanoya city). *8 Map showing forecast areal extent of ash fall. *9 Distance from the crater to maximum extent of area of lapilli fall: $3 \mathrm{~km}$. ${ }^{*} 10 \mathrm{Map}$ showing forecast areal extent of lapilli fall. 

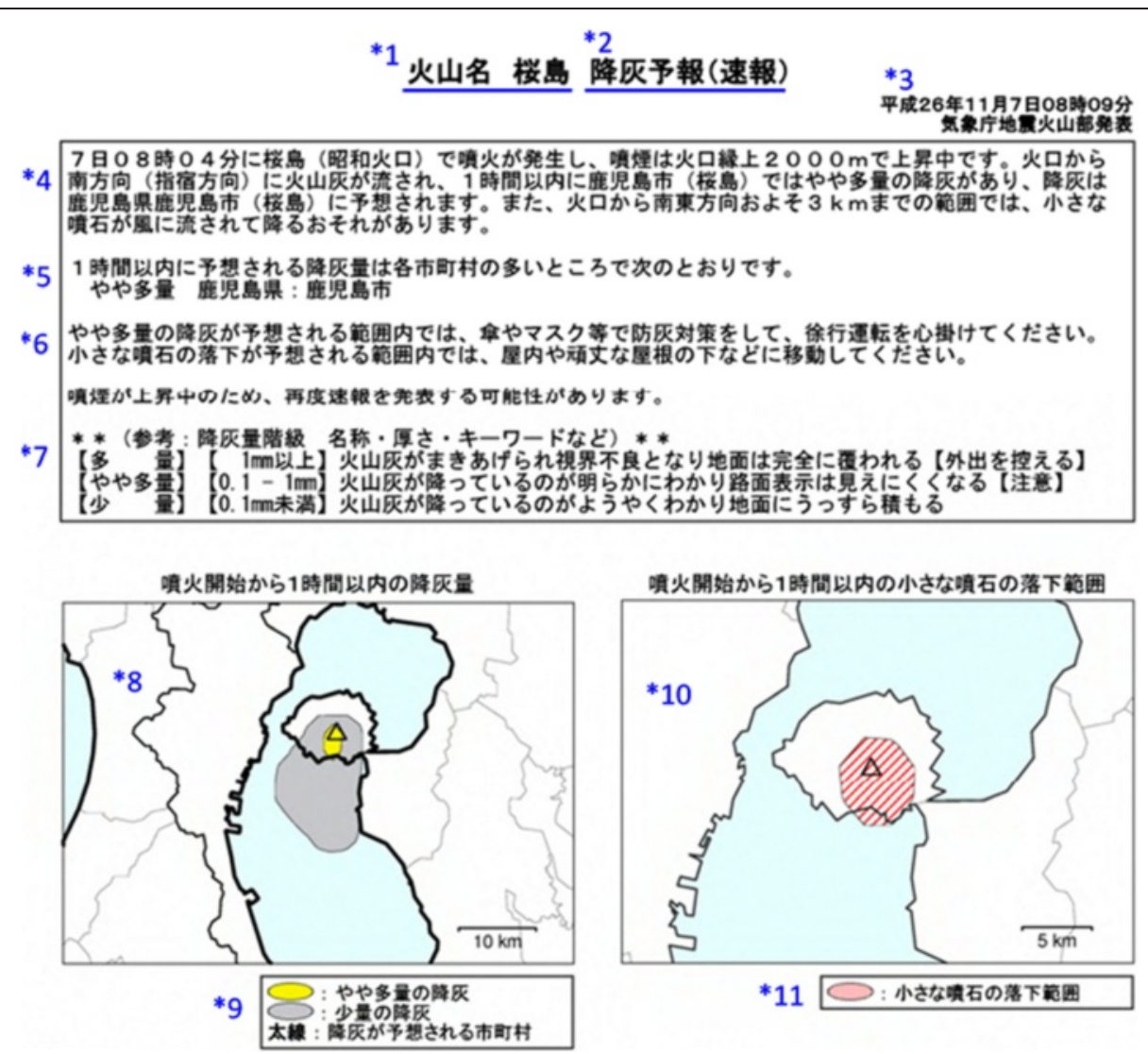

Figure 8 Sample of Preliminary Forecast (graphical format) in the new VAFF format. Translations from Japanese as numbered below. *1 Volcano name: Sakurajima volcano. *2 Forecast title. *3 Time of issue and responsible observatory. *4 Summary: An eruption occurred at 08:04 on November 7. A $2000 \mathrm{~m}$ eruption plume formed and is rising and extending to south. An ash fall of moderate quantity and areal extent of ash fall is forecast for Kagoshima city (Sakurajima) and areal extent of lapilli fall is forecasted to $3 \mathrm{~km}$ away from the crater to south-east direction is forecasted within one hour after onset of the eruption. *5 Forecast of municipalities affected: An ash fall of moderate quantity is forecast in Kagoshima city. *6 Precautions for disaster prevention: People in the open air in areas where a moderate ash fall is forecast should use an umbrella or wear a face mask to minimize their exposure to ash. People driving vehicles should drive slowly. People in areas where a lapilli fall is forecast should stay indoors or take refuge under a solid roof. *7 Reference: Categories of ash fall quantity. Much: Ash deposits more than $1 \mathrm{~mm}$ thick; low visibility by ash fall and roads completely covered by ash; Stay Indoors. Moderate: Ash deposits 0.1 to $1 \mathrm{~mm}$ thick; recognizable ash fall and road markings partly obscured by ash; Attention. Little: thin ash deposits, less than $0.1 \mathrm{~mm}$ thick. *8 Forecast areal extent of ash fall. *9 Legend (ash fall). "Yellow filled area": Area of ash fall of moderate quantity. "Gray filled area": Area of ash fall of little quantity. Thick black line: boundary of municipality to be affected by ash fall. *10: Forecast areal extent of lapilli fall. *11: Legend (lapilli fall). "Red filled area": Area of lapilli fall ( $\geq 1 \mathrm{~cm}$ size).

Therefore, ash-fall quantities will be expressed in three qualitative categories (little, moderate, and much), as proposed by the Working Group on Advanced VAFF. These categories will each be accompanied by estimates of the expected thickness of ash deposits, a simple description (including photos) of the conditions that communities may encounter after an ash fall (road conditions, reduced visibility), and recommended safety precautions to be taken by the general public (Figure 5).

\section{Information about lapilli fall}

The damage caused by lapilli of $\geq 1 \mathrm{~cm}$ size can be considerable (Figure 10 and Table 4). Because lapilli fall faster than ash particles, their arrival at the ground surface precedes that of ash particles. Even for small eruptions with small plumes, considerable damage can be caused by only a few large lapilli. JMA will therefore provide forecasts of areas of lapilli fall where lapilli of $\geq 1 \mathrm{~cm}$ size are expected.

\section{Trial distribution of proposed new VAFF}

Since April 2013, JMA has trialed distribution of the proposed new VAFF (as described above and based on real eruption data) to local government authorities in the region of Sakurajima volcano. In this region, the residents of Kagoshima city (population 600,000) have experienced frequent ash falls for several decades. JMA will use feedback from the trial to further refine the contents of VAFFs and the conditions under which they are issued. 

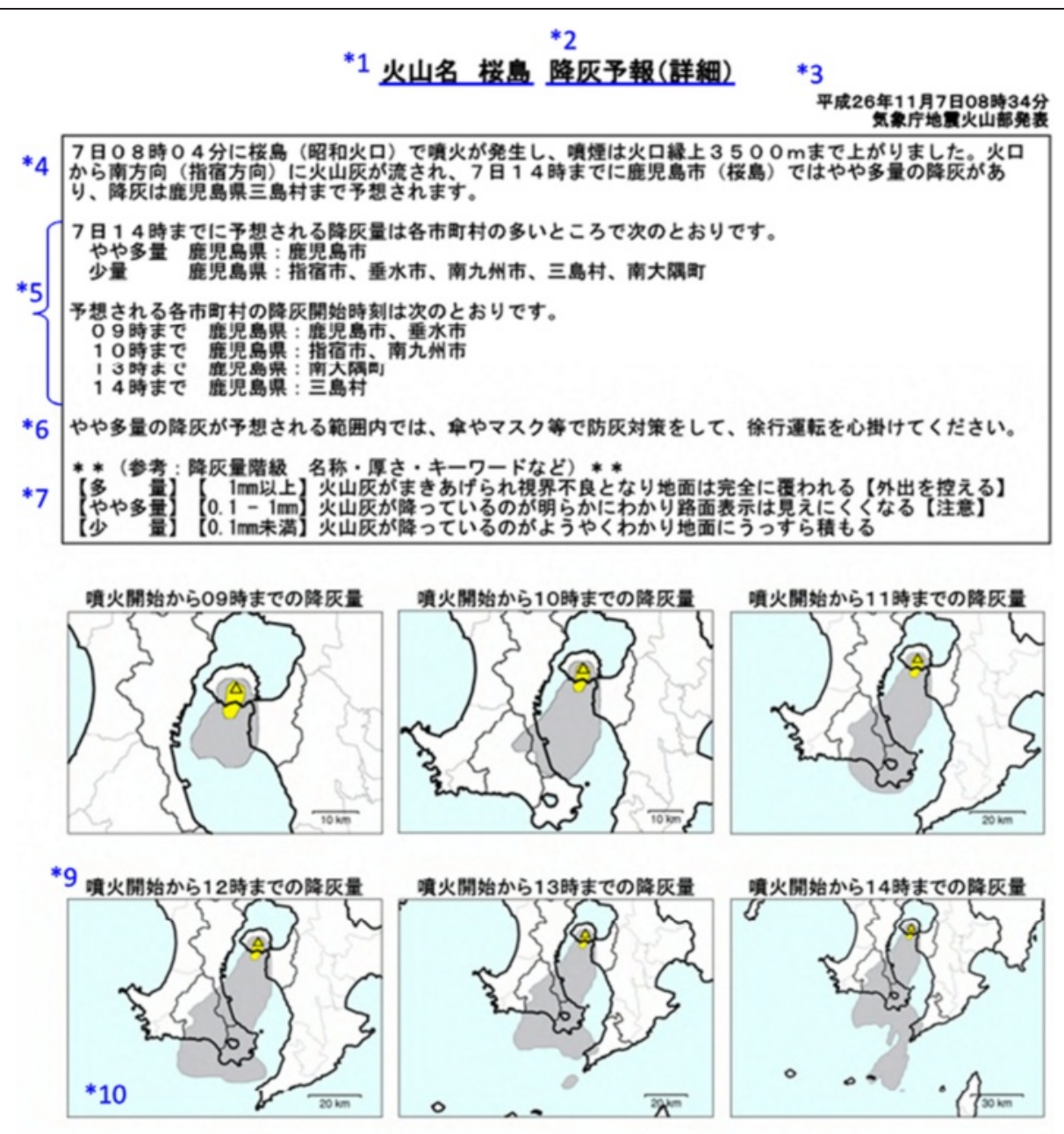

*8

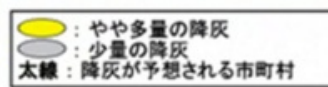

Figure 9 Sample of Full Forecast (graphical format) in the new VAFF format. Translations from Japanese as numbered below. ${ }^{*} 1$ Volcano name: Sakurajima volcano. *2 Forecast title. *3 Time of issue and responsible observatory. *4 Summary: An eruption occurred at 08:04 on November 7. A $3500 \mathrm{~m}$ eruption plume extended to south was observed. An ash fall of moderate quantity is forecast for Kagoshima city (Sakurajima), and areal extent of ash fall is forecasted to Mishima village. *5 Forecast of municipalities affected and start time and quantity of ash fall: Forecasts of ash fall quantity and municipalities affected are as follows. Moderate: Kagoshima city. Little: Ibusuki city et al. Forecast starts of ash fall at municipalities are as follows. Before 09:00 on November 7: Kagoshima city and Tarumizu city. 09:00 to 10:00: Ibusuki city and Minami-kyusyu city. 12:00 to 13:00: Minami-osumi town. 13:00 to 14:00: Mishima village. *6 Precautions for disaster prevention. People in the open air in areas where moderate ash fall is forecast should use an umbrella or wear a face mask to minimize exposure to ash. People driving vehicles should drive slowly. *7 Reference: Categories of ash-fall quantity. Much: Ash deposits more than $1 \mathrm{~mm}$ thick; low visibility by ash fall and roads completely covered by ash; Stay Indoors. Moderate: Ash deposits 0.1 to $1 \mathrm{~mm}$ thick; recognizable ash fall and road markings partly obscured by ash; Attention. Little: thin ash deposits, less than $0.1 \mathrm{~mm}$ thick. *8 Legend: "Yellow filled area": Area of ash fall of moderate quantity. "Gray filled area": Area of ash fall of little quantity. Thick black line: boundary of municipality to be affected by ash fall. *9 Time of forecast shown below $\left({ }^{*} 10\right)$. ${ }^{* 10}$ Forecast areal extent of ash fall for each quantity category.

\section{Further refinements of VAFF system}

JMA and MRI will continue to work together to refine the VAFF system. Areas to be addressed include:

Improvement of RATM-based ash-fall predictions for strong wind conditions and for large-scale eruptions. Development of a method to estimate volcanic plume height, eruption column mass and eruption duration at times when bad weather prevents visual observations and observations using radar data and satellite imagery. Regular examination of the relationship between ashfall quantity and its effect on people, and review of the recommended actions for affected communities. Regular review of the three categories of ash-fall quantity and the thresholds that separate them (Figure 5). 

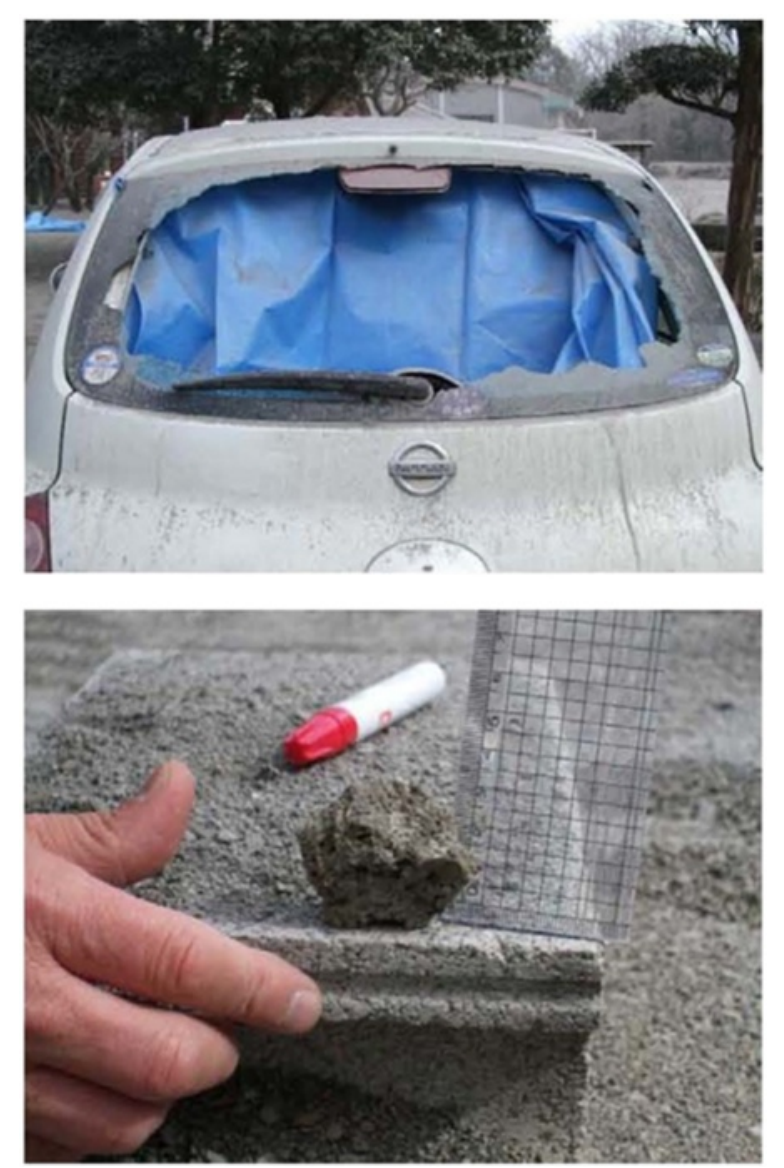

Figure 10 Damage caused by lapilli fall. Top: Rear car window destroyed by lapilli fall (4 to $6 \mathrm{~cm}$ size) $7 \mathrm{~km}$ from the Shinmoedake crater of Kirishimayama volcano. Bottom: Individual lapillus. Individual squares on the ruler are $5 \mathrm{~mm}$ by $5 \mathrm{~mm}$. Photos by JMA (January 27, 2011)

\section{Discussion}

The Working Group on Advanced VAFF (2013b) recommended further work on the accuracy of the JMA ash-fall prediction model RATM, for periods of strong winds and review of the methodology used to calculate the mass of ash in a volcanic plume. These two issues are discussed below.

\section{Effect of strong winds on forecast accuracy}

JMA reviewed the accuracy of lapilli-fall forecasts provided in trial VAFFs issued for eight eruptions of Sakurajima volcano between April 2013 and February 2014. Lapilli falls were observed more than $3 \mathrm{~km}$ from the craters in all cases. With one exception, the actual areas of lapilli fall agreed well with forecasts. The errant forecast was for an eruption on September 4, 2013 (Figure 11), where the forecast area of lapilli fall was clearly smaller than the observed area. During this eruption, wind speed about $500 \mathrm{~m}$ above the volcano was $13 \mathrm{~m} / \mathrm{s}$, whereas wind speeds during the other seven eruptions were $5-10 \mathrm{~m} / \mathrm{s}$.

For initial predictions of areas of ash fall, the JMARATM assumes that ash plumes form a vertical column directly above the crater (Shimbori et al. 2010). Under the influence of strong winds, an ash plume (and the lapilli it contains) may drift leeward and diverge from the vertical, thus resulting in lapilli fall over a greater area than predicted, as was suggested by the Working Group on Advanced VAFF (2013b). Although we do not have sufficient data to allow us to examine ash falls under strong wind conditions, we consider that strong winds will reduce the accuracy of our ash-fall predictions.

The current model for plume formation needs revision to take into account the effect of strong winds (Suzuki and Koyaguchi 2013). In addition, local topographic effects near the volcano, assumed grain-size distribution, and vertical distribution of lapilli in the initial eruption

Table 4 Examples of damage due to lapilli fall after recent eruptions in Japan (since 1970)

\begin{tabular}{|c|c|c|c|}
\hline Volcano & Eruption date (yyyy/mm/dd) & Size of lapilli & Damage \\
\hline Sakurajima & $1983 / 8 / 14$ & $6-7 \mathrm{~cm}$ & Windshield of car, glass pane in front door of house \\
\hline Sakurajima & 1978/7/31 & $5-6 \mathrm{~cm}$ & Injuries to people, car window, house window \\
\hline Sakurajima & $1986 / 6 / 24$ & $5-6 \mathrm{~cm}$ & Windshield of car, slate roof \\
\hline Sakurajima & $1979 / 1 / 5$ & $4-6 \mathrm{~cm}$ & Windshield of car \\
\hline Kirishimayama (Shinmoedake) & $2011 / 1 / 27$ & $4-6 \mathrm{~cm}$ & Window of car \\
\hline Sakurajima & $1983 / 5 / 26$ & $4 \mathrm{~cm}$ & Windshield of car, slate roof \\
\hline Sakurajima & 2000/10/7 & $3 \mathrm{~cm}$ & Window of car, greenhouse \\
\hline Asamayama & $1973 / 2 / 20$ & $3 \mathrm{~cm}$ & Window of car \\
\hline Sakurajima & 1986/8/16 & $2-3 \mathrm{~cm}$ & Windshield of car \\
\hline Kirishimayama (Shinmoedake) & $2011 / 4 / 18$ & $2 \mathrm{~cm}$ & Solar panel and fittings \\
\hline Sakurajima & 1983/8/14 & $1-3 \mathrm{~cm}$ & Window of car \\
\hline Kirishimayama (Shinmoedake) & $2011 / 2 / 14$ & $1.5-2 \mathrm{~cm}$ & Slate roof \\
\hline
\end{tabular}

Table translated into English from Working Group on Advanced VAFF (2013a). 


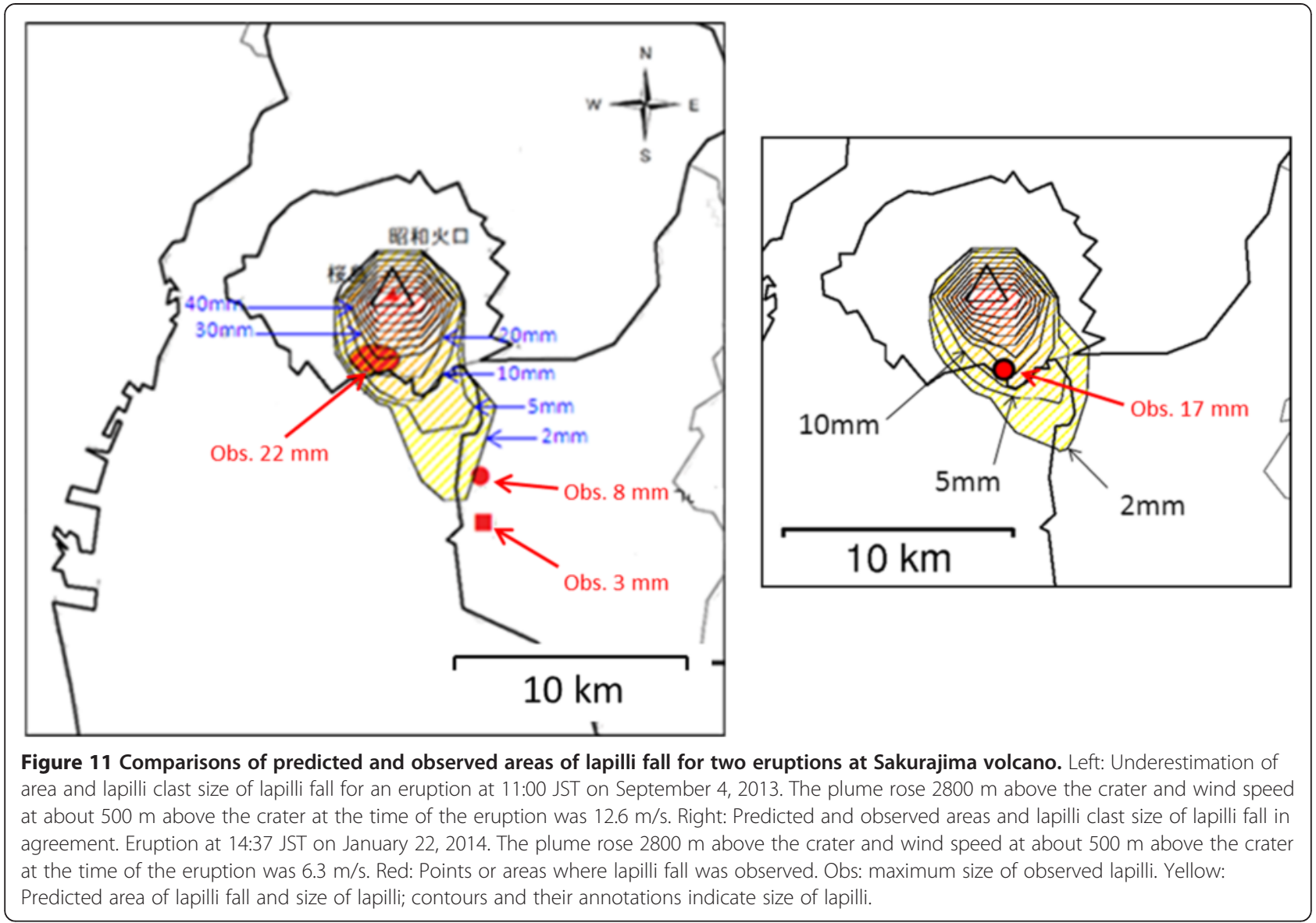

column model also need to be considered adequately. Evaluation of these factors should be the subject of future research.

\section{Estimation of mass of volcanic ash in ash plumes}

The JMA-RATM estimates the mass of volcanic ash in a plume by applying a formula based on empirical data from past eruptions in various parts of the world (plume height, eruption duration, and field data on actual areas of ash fall; Sect. A.2 of Shimbori et al. (2010). To date, we have applied this model regardless of plume size; however, the Working Group on Advanced VAFF (2013b) suggested that this approach might not be accurate for small eruptions.

Between April 2013 and February 2014 there were only four eruptions at Sakurajima volcano for which there were sufficient observations to allow us to compare observed and predicted masses of ash generated. Although our estimate was accurate for the largest of these eruptions (16:31 JST on August 18, 2013), which generated an ash plume that rose $5000 \mathrm{~m}$ above the crater, we underestimated the masses of ash for the three smaller eruptions, which had plume heights of 2400-3300 m.

These results suggest that the estimates of the masses of ash in plumes that we obtained by using the current approach are inaccurate for small eruptions. As suggested by the Working Group on Advanced VAFF (2013b), further study is needed to improve these estimates.

\section{Conclusion}

To improve the current VAFF system and make it a more-effective tool for disaster prevention or mitigation, JMA took into account the needs of VAFF users and the opinions of experts in various fields including disaster prevention organizations. The current VAFF provides only forecasts of areas of ash fall. Important improvements to be implemented in the new VAFF system are the provision of predictions of ash-fall quantity and areas of lapilli fall. Two factors that have made important contributions to these improvements are advances in the methodology for prediction of ash-fall quantity and areas of lapilli fall as a result of studies by MRI, and increased processing capacity of the JMA supercomputer system following a recent upgrade.

The main improvements incorporated in the new VAFF system are as follows.

Three types of VAFF will be sequentially issued: information issued before an eruption (Regular Information), a brief forecast issued within 10 minutes of the onset of an eruption (Preliminary Forecast) and a more extensive 
and accurate forecast issued within 30 minutes of the onset of the eruption (Full Forecast).

VAFFs will be issued in Japanese in both graphical format and text format.

JMA will provide with VAFFs a table that categorizes ash fall by quantity, documents the potential effects on people for each category and the preparedness measures they should take.

VAFFs will be issued for ash falls of moderate and much quantity.

In addition to forecasts of areas of ash fall provided in current VAFFs, the new VAFFs will include predictions of ash-fall quantity and areas of lapilli fall (for lapilli size $\geq 1 \mathrm{~cm}$ ), and recommended precautions for people to take during and after ash and lapilli falls.

JMA plans to start using the new VAFF system in spring 2015, and will continue to review and make further improvements in the future.

\section{Competing interests}

The authors declare that they have no competing interests.

\section{Authors' contribution}

YHas guided the review process of the research, and is the main author of the manuscript. AS contributed to making of format of new VAFF and the categories of ash fall quantity. YoHay contributed to making of format of new VAFF and the categories of ash fall quantity. YuHay contributed to making of format of new VAFF and the categories of ash fall quantity. SS contributed to making of format of new VAFF and the categories of ash fall quantity. TS contributed to improvement of techniques of ash fall prediction. All authors read and approved the final manuscript.

\section{Acknowledgements}

We are grateful to the chairman (Prof. A. Tanaka) and members of the Working Group on Advanced VAFF for their contributions to this project. We thank the people who participated in our survey of the needs of VAFF users near Asamayama, Kirishimayama, and Sakurajima volcanoes, and the organizations that cooperated in our trial distribution of VAFFs near Sakurajima volcano, including local governments and local media. We also thank two anonymous reviewers. Advice about improvements of the VAFF system from Dr. H. Yamasato, S. Harada, and other JMA staff members is much appreciated.

\section{Author details}

${ }^{1}$ Japan Meteorological Agency, Chiyoda-ku, Tokyo, Japan. ${ }^{2}$ Meteorological Research Institute, Tsukuba, Ibaraki, Japan.

Received: 29 May 2014 Accepted: 16 December 2014

Published online: 24 January 2015

\section{References}

Furukawa R (2011) Eruption of Shinmoedake volcano, Kirishima volcano group, 2011. AIST Today 2011-09:15

Hashimoto A, Shimbori T, Fukui K (2012) Tephra fall simulation for the eruptions at Mt. Shinmoe-dake during 26-27 January 2011 with JMA NHM. SOLA 8:37-40, doi:10.2151/sola. 2012-010

Horwell CJ, Baxter PJ (2006) The respiratory health hazards of volcanic ash: a review for volcanic risk mitigation. Bull Volc 69:1-24

JMA (2013) Report of Survey of Needs for Improvement of VAFF (in Japanese)., p 101, http://www.data.jma.go.jp/svd/vois/data/tokyo/STOCK/kouhai/ kentokai/needs.pdf

Mt. Fuji Hazard Map Examination Committee (2004) Report of Mt. Fuji Hazard Map Examination Committee (in Japanese)., p 240, http://www.bousai.go.jp/ kazan/fujisan-kyougikai/report/index.html

Shimbori T, Aikawa Y, Fukui K, Hashimoto A, Seino N, Yamasato H (2010) Quantitative tephra fall prediction with the JMA mesoscale tracer transport model for volcanic ash: A case study of the eruption at Asama volcano in 2009 (in Japanese). Pap Met Geophys 61:13-29, doi:10.2467/mripapers.61.13 Shimbori T, Kai R, Hayashi Y, Hayashi Y, Sugai A, Hasegawa Y, Hashimoto A, Takagi A, Yamamoto T, Fukui K (2014) Tephra fall predictions with the JMA regional atmospheric transport model: A case study of the eruptions at Shinmoe-dake volcano in 2011 (in Japanese). Pap Met Geophys 65:75-107, doi:10.2467/mripapers.65.75

Suzuki T (1990) Potential hazards of pyroclastic air-fall (in Japanese). Bull Inst Vocational Training 19A:1-17

Suzuki YJ, Koyaguchi T (2013) 3D numerical simulation of volcanic eruption clouds during the 2011 Shinmoe-dake eruptions. Earth Planets Space 65:581-589, doi:10.5047/eps.2013.03.009

Wilson TM, Stewart C, Sword-Daniels V, Leonard GS, Johnston DM, Cole JW, Wardman J, Wilson G, Barnard ST (2012) Volcanic ash impacts on critical infrastructure. Phys Chem Earth 45-46:5-23, doi:10.1016/j.pce.2011.06.006

Working Group on Advanced VAFF (2013a) Materials of 3rd Meeting of the Working Group on Advanced VAFF (in Japanese)., http://www.data.jma.go.jp/ svd/vois/data/tokyo/STOCK/kouhai/kentokai/3rd/sankou.pdf

Working Group on Advanced VAFF (2013b) Proposal for Advanced VAFF (in Japanese)., p 27, http://www.jma.go.jp/jma/press/1303/29a/teigen.pdf

\section{Submit your manuscript to a SpringerOpen ${ }^{\circ}$ journal and benefit from:}

- Convenient online submission

- Rigorous peer review

- Immediate publication on acceptance

- Open access: articles freely available online

- High visibility within the field

- Retaining the copyright to your article

Submit your next manuscript at $>$ springeropen.com 